\title{
Analisis Deteksi Fiscal illusion dengan Pendekatan Revenue Enchancement Pada Pengelolaan Keuangan Pemerintah Daerah (Studi Kasus Pada Pemerintah Kabupaten/Kota di Wilayah III Cirebon)
}

\author{
Neni Nurhayati \\ Universitas Kuningan \\ olive_1902@yahoo.com
}

\begin{abstract}
Abstrak
Tujuan penelitian untuk mengetahui determinan kinerja keuangan sekaligus mendeteksi ilusi fiskal yang terjadi. Untuk tujuan ini, selanjutnya penelitian dilakukan pada pendapatan asli daerah sebagai instrumen determinan belanja daerah;. Dana alokasi umum, dana alokasi khusus, daya pajak dan belanja daerah sebagai instrumen determinan pendapatan asli daerah; dan PDRB, pajak daerah, Herfindahl Concentration Taxes, dana alokasi umum, dana alokasi khusus, dana bagi hasil dan lain - lain pendapatan daerah yang sah untuk mendeteksi ilusi fiskal. Populasi Kabupaten/Kota se-Wilayah III Cirebon yang berjumlah 5 Kabupaten/Kota. Dalam penelitian ini dilakukan analisis data menggunakan metode statistik deskriptif dan statistik inferensial yang terdiri dari: uji asumsi klasik, analisis regresi linier berstruktur, analisis koefisien determinasi, uji F, Uji $t$ dan analisis ilusi fiskal. Penelitian selama enam bulan dari bulan April sampai dengan September 2016. Hasil penelitian menunjukkan adanya hubungan yang positif dan signifikan antara PDRB, retribusi, DAU, dan DBH dengan belanja daerah, sedangkan pajak memiliki hubungan yang negatif dan signifikan secara statistik. Hasil penelitian tersebut menunjukkan terjadi ilusi fiskal pada kabupaten dan kota di wilayah III Cirebon.
\end{abstract}

Kata kunci: Fiscal Illusion, Revenue Enchancement, Keuangan Daerah

\section{PENDAHULUAN}

Idealnya setiap penerimaan pemerintah harus berdampak pada besaran pengeluaran dan sebaliknya bahwa semakin besar pengeluaran pemerintah maka pemerintahpun seharusnya memperoleh manfaat dengan meningkatnya penerimaan pemerintah di masa datang. contohnya jika kontribusi pajak meningkat maka seharusnya terjadi hubungan yang simetris antara sisi penerimaan dan pengeluaran pemerintah, namun jika yang terjadi sebaliknya maka hal tersebut dikatakan terjadi ilusi fiskal.

Deteksi ilusi fiskal menurut Priyo, 2009 dapat dilakukan melalui berbagai cara diantara nya adalah dengan menggunakan pengukuran pendapatan yaitu revenue enhancement dan juga dapat dilakukan dengan manipulasi belanja atau disebut expenditure manipulation.

Hal ini mengindikasikan adanya perilaku penyimpangan pemerintah daerah pada transfer dari pemerintah pusat yang diperkirakan mampu meningkatkan pendapatan asli daerah. Meskipun demikian, hal ini memerlukan pembuktian empiris dan menjadi dasar pemikiran dalam penelitian ini.

Menyadari hal tersebut, maka perlu dilakukan analisis terkait deteksi Fiscal illusion pada pengelolaan keuangan daerah. Berdasarkan fenomena tersebut, maka penulis tertarik untuk melakukan sebuah penelitian dengan judul “ Analisis Deteksi Fiscal illusion dengan Pendekatan Revenue Enchancement Pada Pengelolaan Keuangan Pemerintah Daerah (Studi 
Kasus Pada Pemerintah Kabupaten dan Kota di Wilayah III Cirebon).

\section{KERANGKA BERFIKIR}

Kuncoro (2007) dalam Adi (2008), menyebutkan bahwa peningkatan alokasi transfer diikuti dengan pertumbuhan belanja yang lebih tinggi. Ini membuktikan bahwa inefisiensi belanja pemerintah terutama belanja operasional menjadi penyebab terjadinya peningkatan belanja. Pada saat transfer dana pemerintah pusat menurun maka diikuti juga dengan penurunan pada belanja daerah yang melebihi penurunan sisi pendapatan asli daerahnya. Kecenderungan tersebut mengindikasikan tingginya ketergantungan pemerintah daerah kepada pemerintah pusat dimana dalam jangka panjang ketergantungan tersebut sebaiknya harus dikurangi, karena akan berdampak buruk terhadap kemandirian daerah. Lebih lanjut lagi Kuncoro (2007) dalam Adi (2008) menjelaskan bahwa saat masyarakat menerima transfer maka ini akan berdampak juga pada kenaikan penerimaan pajak daerah dan peningkatan pada konsumsi barang publik. Kondisi tersebut menunjukkan bahwa transfer meningkatkan konsumsi akan barang publik namun tidak menjadi substitut pajak daerah. Kondisi sepertri inilah dalam berbagai kajian literatur disebut sebagai flypaper effect. Dua dari beberaapa metode yang bisa dilakukan untuk mendeteksi nya adalah melalui pengukuran pendapatan (revenue enhancement) dan dengan manipulasi belanja (expenditure manipulation).

Deteksi ilusi fiskal menggunakan pengukuran pendapatan mengasumsikan bahwa penerimaan mempunyai hubungan positif dengan belanja. Sehingga jika terdapat hubungan negatif antara variabel-variabel pendapatan dengan variabel belanja, maka terdapat ilusi fiskal.
Sedangkan deteksi terjadinya ilusi fiskal dengan manipulasi belanja dilakukan dengan melihat peran komponen penerimaan terhadap peningkatan anggarannya. Sehingga semakin besarnya penerimaan daerah maka Pendapatan Asli Daerah (PAD) seharusnya juga akan menjadi semakin besar.

\section{METODE PENELITIAN}

Penelitian ini menggunakan metode deskriptif analitis. Populasi penelitian yaitu Laporan Keuangan Pemerintah Daerah (LKPD) 5 Kabupaten dan Kota Se-Wilayah III Cirebon yaitu Kabupaten Cirebon, Kota Cirebon , Kabupaten Kuningan, Kabupaten Majalengka, dan Kabupaten Indramayu. Data sekunder yang digunakan meliputi data Belanja Daerah, PDRB, pajak daerah, retribusi daerah, dan dana perimbangan. Data dikumpulkan selama periode tahun 2011 sampai 2014. Untuk mendeteksi fenomena Fiscal Illusion dilakukan melalui pendekatan pendapatan (revenue enchancement), maka dibangun model persamaan berikut:

\section{InBDit $=\beta 0+\beta 1 \ln P D R B i t-$ \\ $1+\beta 2 \ln$ TAXit-1+ $\beta 3 \ln H C$ Tit- $1+\beta 4 \ln D A U i t-1+\beta 5 \ln D B H i t-1+\mu$ it}

Dimana:

$\mathrm{BD}=$ Belanja Daerah

PDRB $=$ PDRB

TAX $=$ Pajak Daerah

RET $=$ Herfindahl Concentration Taxes (HCT)

DAU = Dana Alokasi Umum

$\mathrm{DBH}=$ Dana Bagi Hasil

i = Kabupaten / Kota ke-i

$\mathrm{t}=$ Tahun ke- $\mathrm{t}$

a. Belanja Daerah (BD) adalah sebuah realisasi belanja yang tertuang dalam APBD pemerintah Kabupaten dan Kota di Wilayah III Cirebon yang mendukung penyelenggaraan 
pemerintahan, pembangunan, dan pembinaan kemasyarakatan. Satuan hitung untuk belanja daerah adalah jutaan rupiah.

b. Produk Domestik Regional Bruto merupakan data statistik yang merangkum perolehan nilai tambah seluruh kegiatan ekonomi di kabupaten dan kota Se- Wilayah III Cirebon pada satu periode tertentu. PDRB yang digunakan dalam penelitian ini atas dasar harga konstan dengan satuan hitung jutaan rupiah.

c. Pajak daerah (PD) adalah pungutan yang dilakukan oleh pemerintah daerah berdasarkan peraturan perundang-undangan yang berlaku. Satuan hitung pajak dengan jutaan rupiah.

d. Herfindahl Concentration Taxes (HCT). Dalam penelitian ini variabel HCT di proksi dari rasio retribusi daerah terhadap total penerimaan retribusi provinsi.

e. Dana Alokasi Umum (DAU) adalah laporan realisasi penerimaan DAU pada laporan keuangan pemerintah daerah. Satuan hitung DAU adalah jutaan rupiah.

f. Dana bagi hasil pajak dan bukan pajak (DBH) adalah laporan realisasi penerimaan DBH pada laporan keuangan pemerintah daerah. Satuan hitung DBH menggunakan jutaan rupiah.

\section{HASIL PENELITIAN \\ Perkembangan Penerimaan Daerah}

Kontribusi penerimaan daerah dalam pelaksanaan pembangunan daerah pada Kabupaten/Kota di Wilayah III Cirebon terbilang cukup baik, terbukti dari adanya peningkatan penerimaan daerah dari tahun ke tahun selama tahun 2011 sampai dengan tahun 2014.
Tabel 4.1 Perkembangan Penerimaan Daerah Kabupaten dan Kota Di Wilayah III Cirebon Tahun 2011 2014 Dalam Jutaan Rupiah

\begin{tabular}{lllll}
\hline Kabupate & Tahun & & & \\
n/Kota & 2011 & 2012 & 2013 & 2014 \\
Kab. & 1781 & 1994 & 2316 & 2733 \\
Cirebon & .243 & .265 & .012 & .580 \\
Kota. & 838. & 872. & 1009 & 1234 \\
Cirebon & 618 & 125 & .950 & .068 \\
Kab. & 1672 & 1885 & 2121 & 2578 \\
Indramay & .538 & .654 & .308 & .255 \\
u & & & & \\
Kab. & 1277 & 1574 & 1791 & 2057 \\
Majaleng & .922 & .352 & .765 & .002 \\
ka & & & & \\
Kab. & 1309 & 1463 & 1625 & 1896 \\
Kuninga & .562 & .419 & .739 & .835 \\
$\mathrm{n}$ & & & & \\
\hline
\end{tabular}

Sumber: Badan Pusat Statistik, data diolah

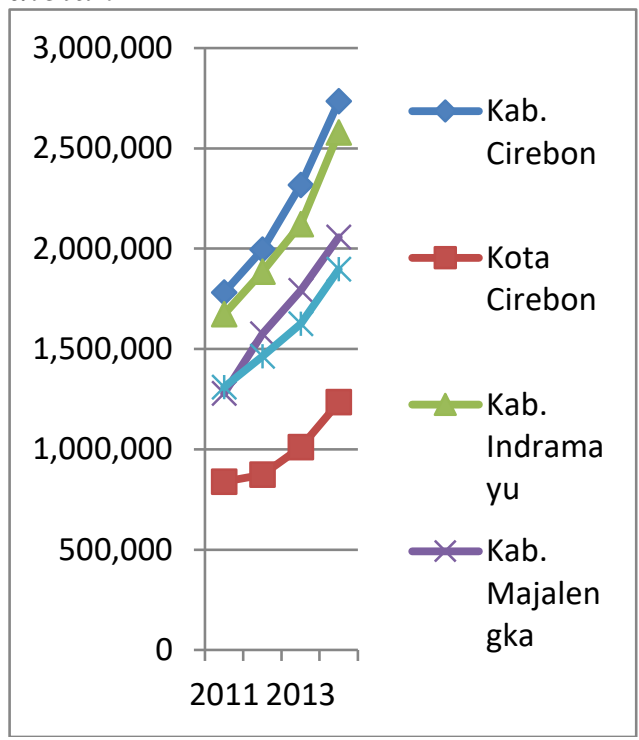

Gambar 4.1 Grafik Perkembangan Penerimaan Daerah Kabupaten/Kota Di Wilayah III Cirebon Tahun 2011 2014.

Tahun 2011 sampai tahun 2014 Kabupaten Cirebon merupakan daerah dengan total penerimaan terbesar diantara kabupaten maupun kota di wilayah III Cirebon, sedangkan daerah dengan penerimaan terendah pada beberapa tahun tersebut adalah Kota Cirebon. 


\section{Perkembangan Pendapatan Asli Daerah}

Kabupaten Cirebon menempati peringkat pertama sebagai daerah dengan PAD terbesar dibandingkan kabupaten/kota di wilayah III Cirebon baik pada Tahun 2011 sampai tahun 2014. Sebaliknya, daerah dengan realisasi penerimaan PAD terkecil yaitu Kabupaten Kuningan.

Tabel 4.2 Perkembangan PAD Kabupaten/Kota Di Wilayah III Cirebon Tahun 2011-2014

\begin{tabular}{lllll}
\hline Kabupate & Tahun & & & \\
n/Kota & 2011 & 2012 & 2013 & 2014 \\
Kab. & 193. & 229. & 250. & 452. \\
Cirebon & 843 & 993 & 849 & 870 \\
Kota. & 120. & 149. & 206. & 298. \\
Cirebon & 131 & 490 & 019 & 541 \\
Kab. & 144. & 164. & 174. & 328. \\
Indramay & 554 & 672 & 713 & 116 \\
u & & & & \\
Kab. & 86.5 & 103. & 142. & 223. \\
Majalengk & 80 & 741 & 506 & 121 \\
a & & & & \\
Kab. & 82.9 & 97.6 & 112. & 202. \\
Kuningan & 17 & 06 & 517 & 518 \\
\hline
\end{tabular}

Sumber: Badan Pusat Statistik, data diolah

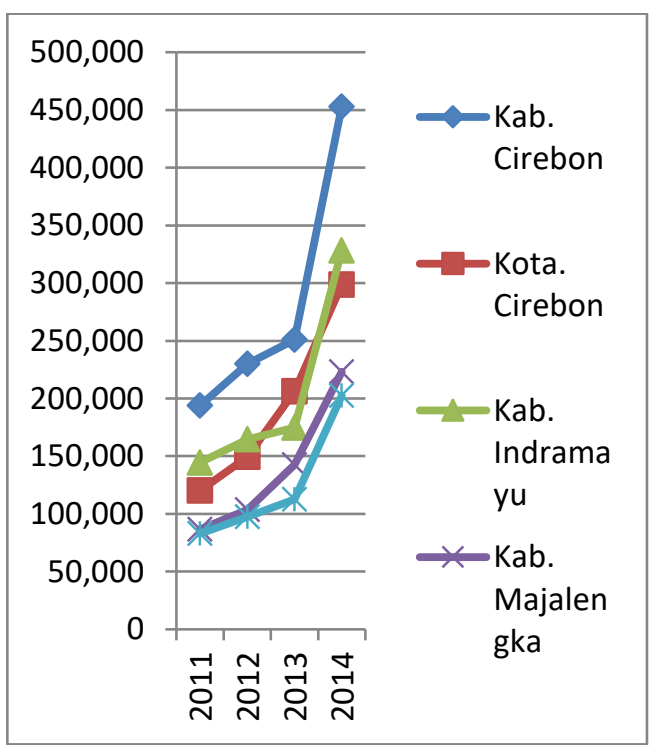

Gambar 4.2 Grafik Perkembangan PAD Kabupaten/Kota Di Wilayah III Cirebon Tahun 2011 - 2015.

\section{Kontribusi PAD Terhadap} Penerimaan Daerah

$$
\text { Rata-rata kontribusi PAD }
$$
terhadap penerimaan daerah kabupaten/kota di wilayah III Cirebon terus mengalami peningkatan walaupun dengan rasio yang masih terbilang relative kecil.

Tabel 4.3 Perkembangan Kontribusi PAD Terhadap Penerimaan Daerah Kabupaten/Kota Di Wilayah III Cirebon Tahun 2011-2014

\begin{tabular}{|c|c|c|c|c|}
\hline \multirow{3}{*}{$\begin{array}{l}\text { Kabupaten/K } \\
\text { ota }\end{array}$} & \multicolumn{4}{|c|}{ Tahun } \\
\hline & 201 & 201 & 201 & 201 \\
\hline & 1 & 2 & 3 & 4 \\
\hline Kab. Cirebon & 10.8 & 11.5 & 10.8 & 16.6 \\
\hline Kota. Cirebon & 14.3 & 17.1 & 20.4 & 24.2 \\
\hline $\begin{array}{l}\text { Kab. } \\
\text { Indramavu }\end{array}$ & 8.6 & 8.7 & 8.2 & 12.7 \\
\hline $\begin{array}{l}\text { Kab. } \\
\text { Majalengka }\end{array}$ & 6.8 & 6.6 & 8.0 & 10.8 \\
\hline $\begin{array}{l}\text { Kab. } \\
\text { Kuningan }\end{array}$ & 6.3 & 6.7 & 6.9 & 10.7 \\
\hline
\end{tabular}

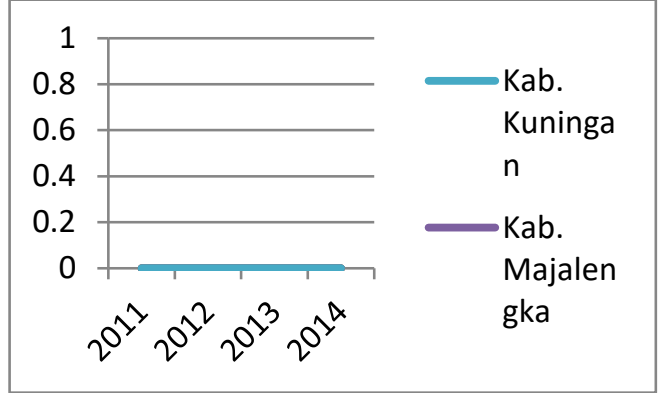

Gambar 4.3 Grafik Perkembangan Kontribusi PAD Terhadap Penerimaan Daerah Kabupaten/Kota Di Wilayah III Cirebon Tahun 20112014

Jika dilihat kontribusi PAD terhadap peneriman daerah selama 
periode tahun 2011 - 2015, maka Kota Cirebon merupakan daerah yang memiliki kontribusi terbesar PAD terhadap penerimaan daerahnya. Sebaliknya, Kabupaten Kuningan merupakan daerah yang memiliki kontribusi PAD terkecil terhadap penerimaan daerahnya.

\section{Perkembangan Dana Perimbangan}

Dana perimbangan yang diterima oleh kabupaten/kota di wilayah III Cirebon tahun 2011 - 2014 terus mengalami peningkatan setiap tahun nya.

Tabel 4.4 Perkembangan Dana Perimbangan Kabupaten/Kota Di Wilayah III Cirebon Tahun 2011-2014

\begin{tabular}{lllll}
\hline Kabupate & Tahun & & & \\
n/Kota & 2011 & 2012 & 2013 & 2014 \\
Kab. & 1099 & 1327 & 1488 & 1585 \\
Cirebon & .402 & .559 & .073 & .728 \\
Kota. & 533. & 653. & 630. & 689. \\
Cirebon & 162 & 010 & 248 & 248 \\
Kab. & 1112 & 1341 & 1442 & 1603 \\
Indramay & .478 & .524 & .566 & .150 \\
u & & & & \\
Kab. & 981. & 1275 & 1171 & 1272 \\
Majaleng & 620 & .449 & .738 & .997 \\
ka & & & & \\
Kab. & 862. & 1038 & 1139 & 1269 \\
Kuninga & 737 & .403 & .711 & .156 \\
n & & & & \\
\hline Sumber: & Badan & Pusat & Statistik, data \\
diolah & & & &
\end{tabular}

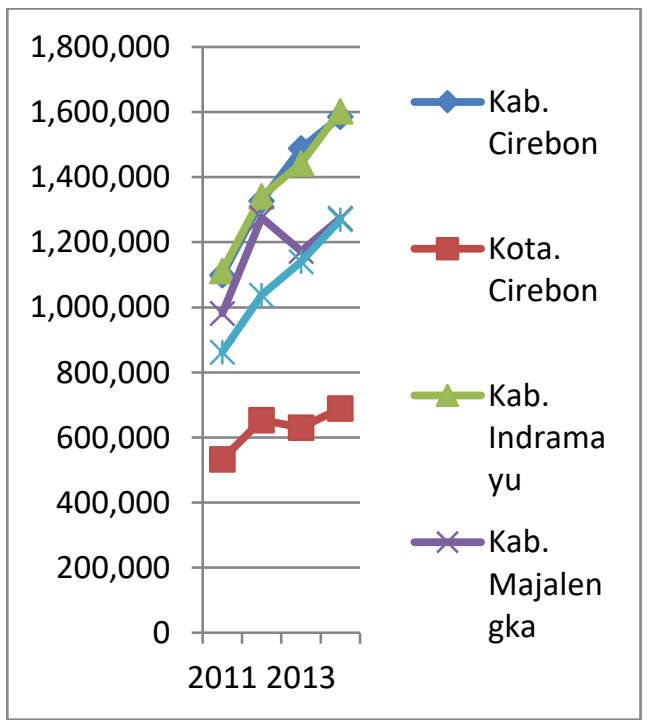

\section{Grafik 4.4 Perkembangan Dana Perimbangan Kabupaten/Kota Di Wilayah III Cirebon Tahun 2011-2014}

Daerah yang menerima dana perimbangan terbesar setiap tahun nya dari tahun 2011-2015 di wilayah III Cirebon adalah Kabupaten Indramayu kecuali pada tahun 2013 penerima dana perimbangan terbesar ada pada Kabupaten Cirebon. sebaliknya, daerah yang menerima dana perimbangan terkecil di wilayah III Cirebon adalah Kota Cirebon.

\subsubsection{Kontribusi Dana Perimbangan Terhadap Penerimaan Daerah}

Kontribusi dana perimbangan terhadap penerimaan daerah di kabupaten/kota di wilayah III Cirebon pada tahun 2012 mengalami peningkatan dari tahun sebelumnya, sedangkan pada tahun 2013 dan 2014 rasio dana perimbangan terhadap penerimaan daerah mengali penurunan. hal tersebut mengindikasikan bahwa telah terjadi penurunan tingkat ketergantungan kabupaten/kota di wilayah III Cirebon terhadapa pemerintah pusat.

$$
\text { Selama tahun 2011-2012, }
$$

Kabupaten Majalengka merupakan daerah yang memiliki kontribusi dana perimbangan terhadap penerimaan daerah terbesar di wilayah III Cirebon, sedangkan pada tahun 2013 dan 2014 Kabupaten Kuningan merupakan daerah yang memiliki kontribusi dana perimbngan terhadap penerimaan daerah terkecil.

\section{Tabel 4.5 Perkembangan Kontribusi} Dana Perimbangan Terhadap Penerimaan Daerah Kabupaten/Kota Di Wilayah III Cirebon Tahun 20112014

\begin{tabular}{lllll}
\hline Kabupaten/Kot & \multicolumn{2}{l}{ Tahun } & & \\
a & 201 & 201 & 201 & 201 \\
& 1 & 2 & 3 & 4 \\
\hline
\end{tabular}




\begin{tabular}{lcccc}
\hline Kab. Cirebon & 61.7 & 66.6 & 64.3 & 58.0 \\
Kota. Cirebon & 63.6 & 74.9 & 62.4 & 55.6 \\
Kab. & 66.5 & 71.1 & 68.0 & 62.2 \\
$\begin{array}{l}\text { Indramayu } \\
\text { Kab. }\end{array}$ & 76.8 & 81.0 & 65.4 & 61.9 \\
$\begin{array}{l}\text { Majalengka } \\
\text { Kab. Kuningan }\end{array}$ & 65.9 & 71.0 & 70.1 & 66.9 \\
\hline
\end{tabular}

Sumber: Badan Pusat Statistik, data diolah

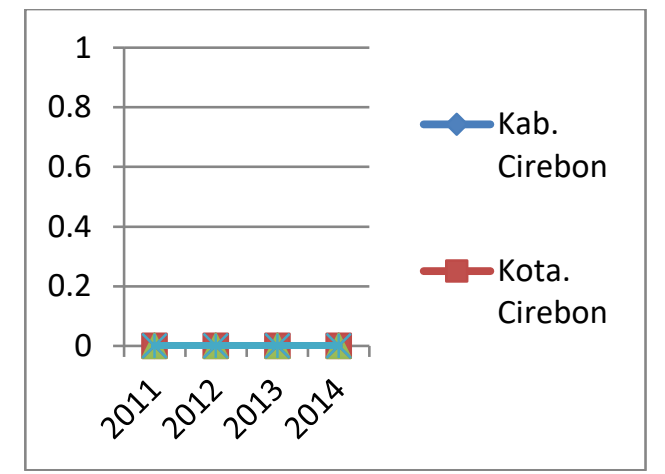

Gambar 4.5 Grafik Perkembangan Kontribusi Dana Perimbangan Terhadap Penerimaan Daerah Kabupaten/Kota Di Wilayah III Cirebon Tahun 2011-2014

\section{Perkembangan Belanja Daerah}

Belanja daerah di kabupaten/kota di wilayah III Cirebon dari tahun 20112014 terus mengalami peningkatan setiap tahunnya. Kabupaten Cirebon pada tahun 2011-2014 merupakan daerah yang memiliki belanja daerah terbesar. Sebaliknya, daerah yang memiliki belanja daerah terkecil pada tahun 2011-2015 diantara kabupaten/kota di wilayah III Cirebon adalah Kota Cirebon.

Tabel 4.6 Perkembangan Belanja Daerah Kabupaten/Kota Di Wilayah III Cirebon Tahun 2011-2014

\begin{tabular}{lllll}
\hline Kabupate & Tahun & & & \\
n/Kota & 2011 & 2012 & 2013 & 2014 \\
Kab. & 1683 & 2033 & 2324 & 2490 \\
Cirebon & .613 & .137 & .459 & .895 \\
Kota. & 818. & 813. & 975. & 1194 \\
Cirebon & 299 & 672 & 250 & .449 \\
Kab. & 1569 & 1843 & 2120 & 2548 \\
Indramay & .018 & .451 & .263 & .895 \\
\hline
\end{tabular}

\begin{tabular}{lcccc}
\hline $\mathrm{u}$ & & & & \\
Kab. & 1287 & 1525 & 1727 & 2009 \\
Majaleng & .193 & .083 & .794 & .725 \\
$\mathrm{ka}$ & & & & \\
$\mathrm{Kab}$. & 1247 & 1434 & 1576 & 1755 \\
Kuninga & .379 & .012 & .542 & .759 \\
$\mathrm{n}$ & & & & \\
\hline Sumpr: & Badan & Pusat & Statistik, data
\end{tabular}

Sumber: Badan Pusat Statistik, data diolah

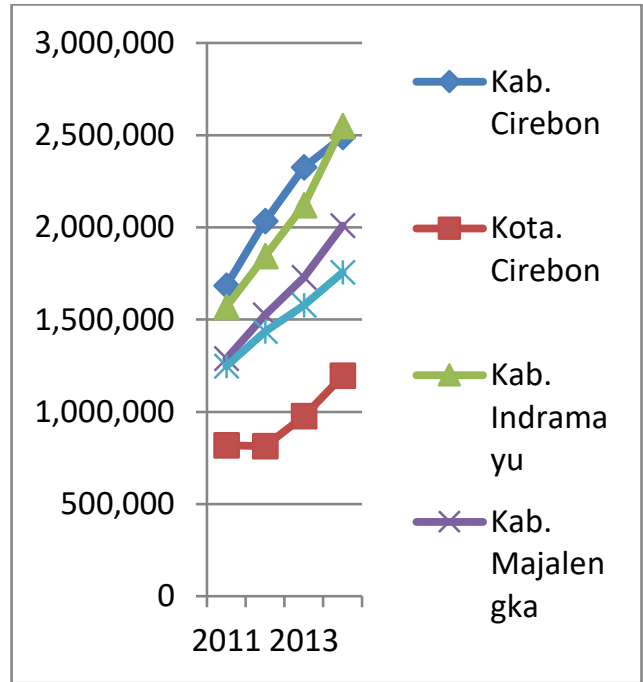

Grafik 4.6 Perkembangan Belanja Daerah Kabupaten/Kota Di Wilayah III Cirebon Tahun 2011-2014

\section{Deteksi Ilusi Fiskal}

Hasil estimasi dengan menggunakan model PLS adalah sebagai berikut:

Dependent Variable: BD

Method: Least Squares

Date: 12/13/16 Time: 16:32

Sample: 120

Included observations: 20

\begin{tabular}{|c|c|c|c|c|}
\hline $\begin{array}{l}\text { Variabl } \\
\mathrm{e}\end{array}$ & $\begin{array}{l}\text { Coeffic } \\
\text { ient }\end{array}$ & Std. Error & $\begin{array}{l}\mathrm{t}- \\
\text { Statistic }\end{array}$ & Prob. \\
\hline $\mathrm{C}$ & 2.252 & 116180.5 & $\begin{array}{l}1.9388 \\
20\end{array}$ & 0.0430 \\
\hline PDRB & 0.147 & 2520.690 & $\begin{array}{l}0.4551 \\
11\end{array}$ & 0.0460 \\
\hline $\begin{array}{l}\text { PAJA } \\
\mathrm{K}\end{array}$ & -0.107 & 0.858589 & $\begin{array}{l}- \\
3.1535 \\
57\end{array}$ & 0.0070 \\
\hline $\begin{array}{l}\text { RETRI } \\
\text { BUSI }\end{array}$ & 0.569 & 1.985509 & $\begin{array}{l}1.7975 \\
27\end{array}$ & 0.0438 \\
\hline DAU & 0.491 & 0.119936 & $\begin{array}{l}2.4380 \\
02\end{array}$ & 0.0000 \\
\hline
\end{tabular}




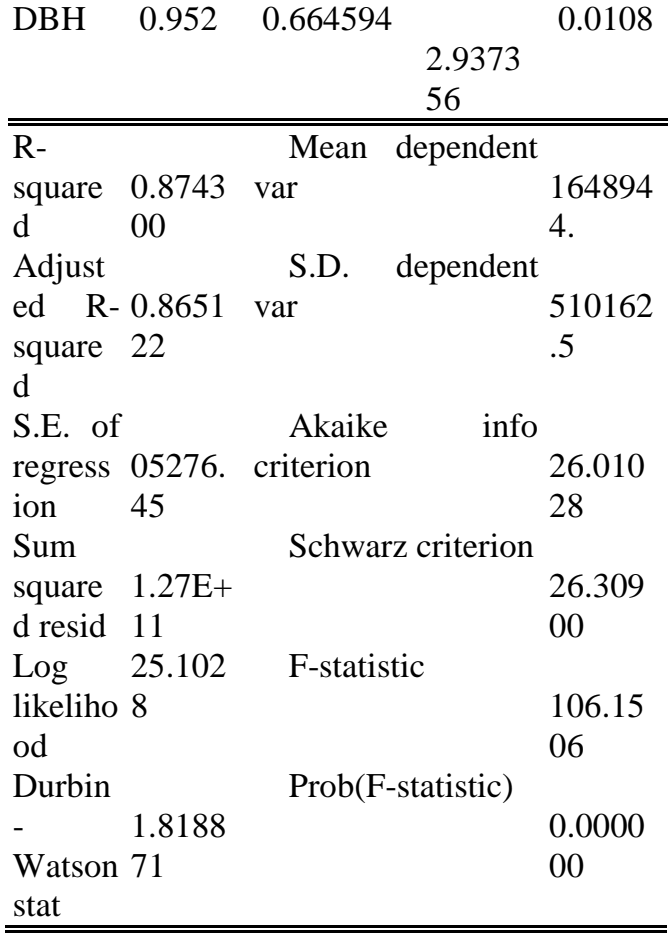

Estimation Command:

\section{LS BD C PDRB PAJAK RETRIBUSI DAU DBH}

Estimation Equation:

$\mathrm{BD}=\mathrm{C}(1)+\mathrm{C}(2) * \mathrm{PDRB}+$
$\mathrm{C}(3) * \mathrm{PAJAK}+\mathrm{C}(4) * \mathrm{RETRIBUSI}+$
$\mathrm{C}(5) * \mathrm{DAU}+\mathrm{C}(6) * \mathrm{DBH}$

Substituted Coefficients:

$\mathrm{BD}=2.252+\quad 0.147 * \mathrm{PDRB}+-$
$0.107 *$ PAJAK $+\quad 0.569 *$ RETRIBUSI +
$0.491 * \mathrm{DAU}+0.952 * \mathrm{DBH}$

Hasil analisis menunjukkan bahwa bahwa model regresi dapat digunakan untuk memprediksi belanja daerah p-value < 5\%. angka Adjusted R squared sebesar 0.865122 menunjukkan $86,5 \%$ belanja daerah dapat dijelaskan oleh PDRB, pajak,retribusi, DAU, dan DBH. secara parsial variabel PDRB, pajak, retribusi, DAU, dan DBH menunjukkan pengaruh yang signifikan.
PDRB, retribusi, DAU, dan DBH memiliki hubungan yang positif dan signifikan dengan belanja daerah. sedangkan pajak memiliki hubungan negatif dan signifikan. Berdasarkan hasil tersebut maka dapat disimpulkan terjadi ilusi fiskal pada kabupaten dan kota di wilayah III Cirebon.

Terjadinya ilusi fiskal pada kabupaten dan kota di wilayah III Cirebon ditunjukan oleh pengaruh negatif signifikan antara pajak daerah dengan belanja daerah dapat disebabkan karena ketergantungan daerah pada transfer pemerintah pusat sangat tinggi, meskipun pajak daerah turun tetapi pemerintah daerah tetap menganggarkan belanja daerah lebih besar dari tahun tahun sebelumnya karena ketergantungan untuk mendapatkan dana transfer dari pusat.

\section{KESIMPULAN DAN SARAN \\ Kesimpulan}

Terdapat fenomena ilusi fiskal dalam kinerja keuangan pemerintah daerah Kabupaten dan Kota di Wilayah III Cirebon.

\section{Saran}

a) Penting bagi daerah untuk melakukan optimaisasi penerimaan daerah khususnya yang bersumber dari PAD dengan berbagai strategi misalnya untuk meningkatkan pajak daerah maka pemerintah daerah dapat melakukan strategi intensifikasi dan ekstensifikasi pajak daerah

b) Pemerintah daerah harus lebih efisien dalam menggunakan dana yang diterima dari pusat. Misanya dengan mengalokasikan dana perimbangan tersebut pada sectorsektor pembangunan 
c) Pemerintah pusat diharapkan dapat lebih cermat mengawasi setiap penggunaan dana perimbangan yang diberikan kepada daerah agar dana tersebut bisa tepat sasran dan tepat guna.

\section{DAFTAR PUSTAKA}

Bhakti, Adi. 2013. Deteksi Ilusi Fiscal Kabupaten/Kota Di Provinsi Jambi (Pengujian Perilaku Asimetris Pemerintah Daerah Dalam Merespon Dana Perimbangan). Jurnal Perspektif Pembiayaan Dan Pembangunan Daerah Vol. 1 No. 2, Oktober 2013. Fakultas Ekonomi Universitas Jambi.

Kuncoro, Haryo. 2001. Tinjauan Literatur Ekonomi Politik dan Pengaruh Transfer ada Kinerja Keuangan Sektor Publik.

Kuncoro, Haryo, 2007, Perilaku Asimetris Pemerintah Daerah Kota dan Kabupaten AtasPerubahan Besaran Transfer dari Pemerintah Pusat, The 1st Accounting Conference Faculty of Economic Universitas Indonesia.

Peraturan Menteri Dalam Negeri No. 13 Tahun 2006 tentang Pengelolaan Keuangan Daerah

Peraturan Menteri Dalam Negeri Nomor 29 Tahun 2009 Tentang Pedoman pengurusan, pertanggungjawaban dan pengawasan keuangan daerah serta tata cara penyusunan anggaran pendapatan dan belanja daerah, pelaksanaan tata usaha keuangan daerah dan penyusunan perhitungan anggaran pendapatan dan belanja daerah

Peraturan Pemerintah Republik Indonesia, UU No.17 Tahun 2003 tentang Keuangan Negara

Peraturan Pemerintah Republik Indonesia, Undang-undang No. 32 Tahun 2004 tentang Pemerintah Daerah.

Peraturan Pemerintah Republik Indonesia, Undang-undang Nomor 33 Tahun 2004 tentang Perimbangan Keuangan Antara Pemerintah Pusat dan Pemerintah Daerah.

Peraturan Pemerintah Republik Indonesia, Undang-undang Nomor 58 Tahun 2005 tentang Pengelolaan Keuangan Daerah

Priyo, Hari Adi \& Ekaristi, Puspa Dewi. 2009. Fenomena Ilusi Fiskal Dalam Kinerja Anggaran Pemerintah Daerah. Jurnal Akuntansi dan Keuangan Indonesia Volume 6 No. 1. Fakultas Ekonomi Universitas Kristen Satya Wacana Salatiga.

Oates, Wallace E. 1999. An Essay on Fiscal Federalism. Journal of Economic Literature Vol. XXXVII (September 1999) pp. 1120-1149 